\title{
UPAYA PENGUATAN KESEJAHTERAAN PSIKOLOGIS KAUM JANDA LANSIA DENGAN PENDEKATAN KASIH SAYANG (STUDI DI LSM LUH JINGGAN PONDOK PESANTREN AL-KAMAL TAMBAKSARI KUWARASAN KEBUMEN JAWA TENGAH)
}

\author{
Azam Syukur Rahmatullah \\ Program Studi Psikologi Pendidikan Islam \\ Pascasarjana Universitas Muhammadiyah Yogyakarta \\ Yogyakarta, Indonesia \\ e-mail:azamsyukurrahmatullah@yahoo.co.id
}

\begin{abstract}
Abstrak
Tingkat pertumbuhan kaum janda lansia pertahun meningkat, terutama janda lansia yang tidak menikah lagi. Mereka sangat membutuhkan hal-hal yang menjadikan tingkat kesejahteraan psikologis meningkat. Oleh karenanya perlu program kegiatan yang menjadikan mereka damai, nyaman serta sejahtera. Dalam hal ini terdapat Lembaga Swadaya Masyarakat yang diberinama LSM Luh Jinggan yang berada di bawah naungan Madrasah Aliyah Plus Nururrohmah Pondok Pesantren Al-Kamal Tambaksari Kuwarasan Kebumen, yang memiliki berbagai program kegiatan yang berupaya untuk mensejahterakan psikologis kaum janda lansia. Berbagai kegiatan tersebut berada pada bingkai pendekatan kasih sayang, yakni secure attachment, high motivation, friendship, personal adjusment, dan rich of religious-illahiyah.
\end{abstract}

Kata Kunci: Janda Lansia, LSM Luh Jinggan, Pendekatan Kasih Sayang, Kesejateraan Psikologis 


\section{A. Pendahuluan}

Menjadi janda bagi seorang perempuan tentu saja bukan pilihan, apalagi kondisi menjanda pada masa tua yang kurang ilmu, kurang harta, kurang skill, dan kurang tenaga. Kurang ilmu berarti sang janda tua sejak masa muda dan dewasa tidak memiliki bekal keilmuan-formal yang cukup. Mereka tidak menikmati bangku sekolah, bahkan kuliah sehingga di akhir masa tuanya mereka tidak mampu menggunakan keilmuan yang seharusnya dimiliki sejak dini dengan baik. Akibatnya, mereka merana dan tidak berdaya untuk menghidupi diri mereka sendiri. Kurang harta bisa dimaknai seorang janda tua ketika ditinggalkan suami tercinta tidak dibekali harta berlebih, bahkan cenderung kurang sehingga akibatnya ketika menjanda dalam kondisi yang kurang, bahkan tidak nyaman sama sekali karena tidak memiliki harta.

Kurang skill bagi seorang janda tua dapat dimaknai bahwa mereka tidak memiliki kemampuan lain yang dapat diandalkan, yang sejatinya meskipun secara keilmuan formal tidak dimiliki, namun apabila memiliki kelebihan skill lain tentu saja mampu membawa para janda dalam posisi nyaman, karena mampu menghidupi diri mereka sendiri. Namun dalam hal ini disebabkan minimnya skill yang dimiliki mengakibatkan mereka menderita di masa tua. Sementara itu, yang dimaksud dengan kurang tenaga adalah posisi daya tahan dan kekuatan para kaum janda tua yang semakin melemah sehingga tidak mampu memaksimalkan dengan baik. Akibatnya mereka hanya bisa bekerja sesuai dengan kekuatan yang semakin melemah tersebut sehingga wajar apabila ending-nya mereka tidak mampu mendapatkan uang yang layak untuk menghidupi keseharian mereka.

Berbagai macam kelemahan dan kekurangan para janda di atas semakin diperparah dengan ketidakpunyaan anak, atau memiliki anak tetapi justru menjadi beban para kaum janda tua tersebut. Akibatnya, para janda tua semakin tertekan dalam hidup. Mereka terkadang merasa bingung akan menggantungkan keluh kesah kepada siapa. Hal ini menjadikan mereka jauh dari penyebutan istilah "kesejahteraan psikologis di masa tua." Masa tua yang idealnya menjadi masa keemasan hidup yakni masa penuh kenyamanan, kedamaian, penyatuan kepada Tuhan, justru menjadi masa paling buruk dalam sejarah kehidupannya karena banyak memiliki kekurangan dan kelemahan. 
Sehubungan dengan kondisi di atas, terdapat Lembaga Swadaya Masyarakat (LSM) yang bernama Luh Jinggan yang berada di Desa Tambaksari Kuwarasan Kebumen. LSM ini menstressingkan diri khusus membantu para kaum janda tua yang tidak mampu dan lemah secara materi dan immateri. Selain itu, LSM ini memberikan pendampingan kepada para kaum janda tua yang mengalami problem psikis dan mental, yang dalam hal ini pihak LSM membantu mencerahkan para kaum janda agar kembali menemukan jalan terang dan mampu melanjutkan kehidupannya secara gemilang, serta meraih predikat kesejahteraan psikologis, sesuatu yang banyak dituju dan menjadi idaman manusia. Berbagai cara yang digunakan oleh pihak LSM Luh Jinggan sangat kuat dan kental nuansa kasih sayang,

Melalui tulisan ini, penulis bermaksud menggali lebih dalam perihal apa dan bagaimana upaya LSM Luh Jinggan membantu para kaum janda tua melewati masa-masa sulitnya dan membantu mereka mendapatkan predikat kesejahteraan psikologis. Di sisi lain, penulis ingin mengetahui perihal program-program apa saja yang dilaksanakan oleh LSM tersebut yang berpondasikan kasih sayang. Harapannya dengan tulisan ini akan diperoleh formulasi yang tepat dalam hal menangani para kaum janda tua.

\section{B. Janda Lansia dalam Konteks Kekinian}

Tingkat pertumbuhan kaum lansia di Indonesia semakin tinggi. Hal ini dapat dibuktikan dengan data dari Kementerian Kesehatan Republik Indonesia yang menyebutkan bahwa berdasarkan sensus penduduk pada tahun 2010, jumlah lanjut usia di Indonesia, yaitu 18,1 juta jiwa (7,6\% dari total penduduk). Pada tahun 2014, jumlah penduduk lanjut usia di Indonesia menjadi 18,781 juta jiwa dan diperkirakan pada tahun 2025, jumlahnya akan mencapai 36 juta jiwa. ${ }^{1}$

Menurut data yang akurat dari Kementerian Kesehatan Republik Indonesia melalui Buletin Jendela Data dan Informasi Kesehatan tahun 2013 dinyatakan bahwa berdasarkan jenis kelamin, pola status perkawinan antara lansia laki-laki dan lansia perempuan tidaklah sama. Hal ini sesuai dengan

1 http://www.depkes.go.id/article/view/15052700010/pelayanan-dan-peningkatan-keseha tan-usialanjut.html\#sthash.hD42NLna.dpuf, diakses pada tanggal 25 Juni 2016 
data yang dihasilkan secara parsial bahwa lansia perempuan lebih banyak yang berstatus cerai mati, yakni sekitar 59, 15\%, sedangkan untuk lansia laki-laki lebih banyak yang menikah lagi atau berstatus kawin,yakni sekitar 82,71\%. Menurut penjelasan yang diuraikan pada Buletin Jendela tersebut bahwa status perkawinan lansia adalah persentase yang cukup tinggi dari lansia perempuan yang berstatus cerai. Hal ini disebabkan sebagian besar perempuan setelah cerai tidak kawin lagi dalam jangka waktu yang relatif lama. Sebaliknya, lansia laki-laki yang bercerai umumnya segera kawin lagi. ${ }^{2}$

Kondisi yang kebanyakan lansia perempuan tidak menikah lagi inilah yang menjadikan para janda lansia banyak mengalami problem dalam menciptakan kesejahteraan psikologis diri, terutama problem dalam menyambung hidup dan menyelesaikan problem-problem psikis. Sebagaimana hasil penelitian Enita Fitrianingrum dan Martinus Legowo yang kemudian ditulis dalam jurnal berjudul "Strategi Bertahan Hidup Janda Lansia", melalui penelitian tersebut terlihat bahwa para janda lansia untuk menopang kehidupannya agar tetap bisa berjalan meskipun harus tertatih-tatih menggunakan tiga pendekatan, yakni pertama, mengikat sabuk lebih kencang, yang berarti mereka menyengaja diri untuk makan hanya sekali atau dua kali dalam sehari. Hal ini difungsikan agar mereka bisa menahan lapar. Kondisi yang demikian tentu saja disebabkan krisis atau lemahnya perekonomian yang dimiliki. ${ }^{3} \mathrm{Di}$ sisi lain, dimungkinkan faktor lebih mendahulukan memberi makan anak-anak atau cucu-cucu mereka daripada diri mereka sendiri. Prinsip yang dipegang adalah "biarkan diri ini kelaparan asalkan jangan sampai anak dan cucu yang kelaparan.”

Cara kedua yang dilakukan kaum janda lansia untuk menyambung hidup adalah menggunakan alternatif subsistensi, yakni memberdayakan diri dengan berjualan ringan, seperti berjualan gorengan, makanan ringan, atau menjadi tukang penjaga toko, penjaga warung makan, dan berbagai kegiatan yang selaras dengan tenaga yang dimilikinya. Hal kesemua itu dilakukan agar kehidupannya terus bisa berjalan dengan baik. Selanjutnya cara ketiga adalah menfungsikan relasi atau jaringan sosial. Dalam hal ini para janda lansia memanfaatkan perkenalan atau relasinya untuk membantu mencarikan

2 Buletin Jendela Data dan Informasi Kesehatan, semester I tahun 2013, ISSN 2088-270X

3 Enita Fitrianingrum dan Martinus Legowo, "Strategi Bertahan Hidup Janda Lansia”,Dalam Jurnal Paradigma. Volume 02 Nomer 03 Tahun 2014 
pekerjaan atau justru memberinya pekerjaan. Apapun jenis pekerjaan akan dikerjakan oleh janda lansia, yang terpenting bagi mereka selaras dengan kekuatan yang dimiliki.

Dari pemaparan hasil penelitian tersebut terlihat dengan jelas bahwa para kaum janda lansia yang memiliki kelemahan atau kekurangan sebagaimana yang telah penulis paparkan pada bab pendahuluan, yakni kekurangan ilmu, tenaga, skill, dan harta, memang benar-benar merasakan penderitaan yang tidaklah ringan. Kondisi tersebut dijalani bertahun-tahun, yang tentu saja akan menyebabkan secara kejiwaan sang janda lansia mengalami tekanan, beban mental, yang dimungkinkan akan berujung pada penyakit psikosomatik dan somapsikotik. Hasil penelitian Yanih Mardiana dan Zelfino menunjukkan bahwa dari sekitar 60 lansia yang diantaranya adalah para janda lansia diberi 18 bentuk pertanyaan mengenai tingkat stress yang dilakukan di daerah Kunciran Tangerang. Hasilnya dapat ditemukan 51 reponden (85\%) lansia mengalami tingkat stress dan beban mental, sedangkan lansia yang mengalami hipertensi hanya sekitar 30 responden $(50 \%){ }^{4}$

Hasil penelitian Yanih dan Selfino semakin memperkuat dugaan bahwa para lansia terutama janda lansia memiliki tingkat stress dan tekanan mental yang tinggi. Mereka rentan terjangkiti gangguan-gangguan perasaan seperti cemas, takut, gelisah, was-was, yang pada akhirnya apabila terus-menerus terjadi tanpa adanya "perhatian khusus" akan mengarah pada gangguan kejiwaan. Menurut Moeljono Notosoedirjo dan Latipun tidak hanya rawan gangguan kejiwaan, tetapi para lansia apalagi janda lansia rawan terkena gangguan kepribadian dan mengalami mentality disorder (gangguan mental). ${ }^{5}$ Oleh karenanya menurut Kartini Kartono, para lansia harus mendapatkan perhatian yang lebih terutama dari orang-orang terdekatnya, paling tidak mampu membuat nyaman, damai, tenang kejiwaannya, sehingga para lansia terkhusus janda lansia akan terjaga dari gangguan-gangguan yang telah tersebut di atas. ${ }^{6}$

4 Yanih Mardiana dan Zelfino, "Hubungan Antara Tingkat Stress Lansia dan Kejadian Hipertensi pada Lansia di RW 01 Kunciran Tangerang”, Forum Ilmiah, Volume 11 Nomor 2, Mei 2014

5 Moeljono Notosoedirdjo\&Latipun Kesehatan Mental, Konsep dan Penerapan (Malang: UMM Press, 2014), hlm.23.

6 Kartini Kartono, Patologi Sosial, Gangguan-Gangguan Kejiwaan, (Jakarta: PT Raja Grafindo Persada, 2010). hlm.13. 


\section{Mensejahterakan Psikologi Kaum Janda Lansia dengan Pendekatan Kasih Sayang}

Dalam kondisi yang rentan dan tidak memiliki banyak kelebihan, para janda lansia memang membutuhkan media yang mampu mensejahterakan psikologis mereka. Sebab, dengan kesejahteraan psikologis itulah akan mengurangi tingkat stressing dan tekanan-tekanan yang mengarahkan pada zona ketidaknyamanan diri. Menurut penulis ada beberapa hal mendasar yang dibutuhkan para janda lansia, yang kesemua itu berada pada bingkai "pendekatan kasih saying."Beberapa hal yang dimaksud antara lain:

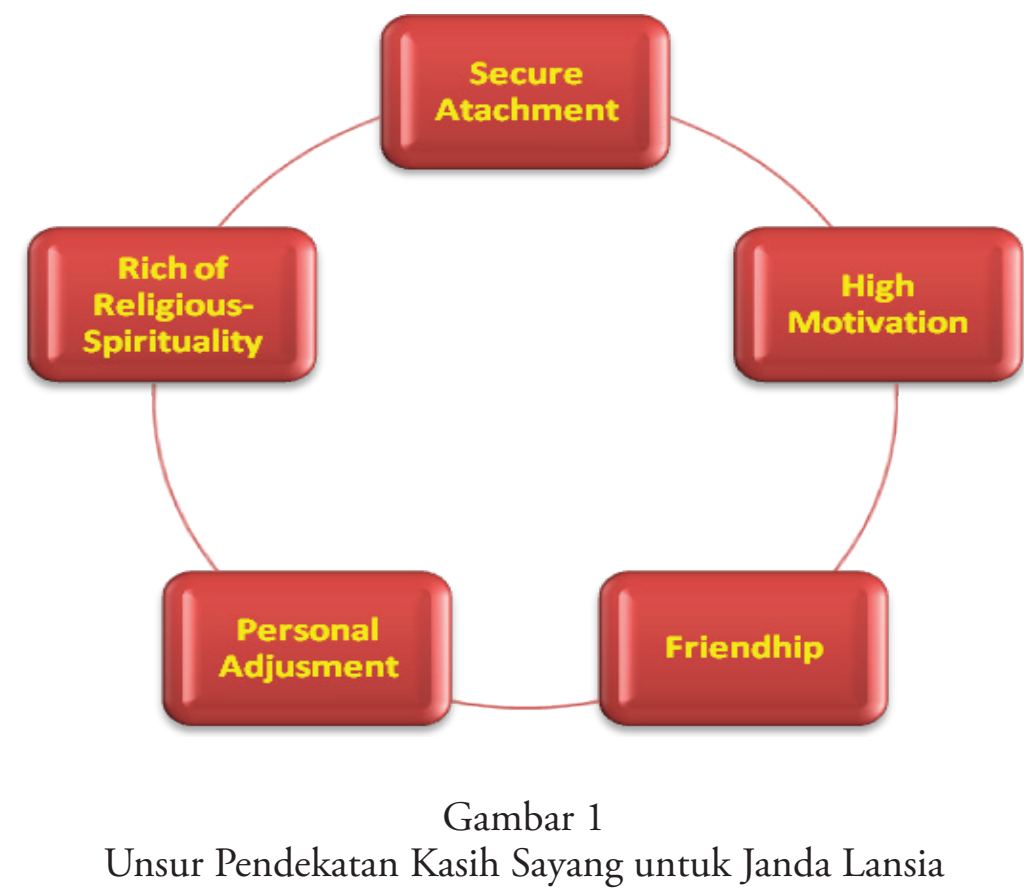

Secure attacment, merupakan bentuk kelekatan yang aman yang diperuntukkan bagi para janda lansia. Secure attachment bisa dimaknai pula dengan memberikan keamanan, kedamaian, dan hal-hal yang membuat para janda lansia tenang serta tidak menggelisahkan jiwa mereka. Dalam penelitian disertasi Azam Syukur Rahmatullah dinyatakan bahwa nuansa yang paling kuat dalam sekup secure attachment adalah adanya penguatan emosional untuk 
menghadirkan kehangatan serta keharmonisan yang nyata, sehingga dengan kondisi yang demikian seseorang yang berada pada zona tersebut akan benarbenar merasakan kebahagiaan yang tidak semu. Hal kedua yang berada pada bingkai kasih sayang adalah motivasi yang berkualitas kepada para kaum janda lansia. $^{7}$

Dengan berbagai kelemahan yang dimiliki tidak hanya harta yang dibutuhkan, tetapi ada tahapan selanjutnya yang diinginkan para janda lansia, yakni motivasi hidup. Motivasi ini sangat diperlukan bagi mereka untuk mengarahkan para kaum janda pada derajat subjective well being. Menurut Azam Syukur Rahmatullah dalam buku berjudul Psikologi Penderitaan dinyatakan bahwa seseorang yang berhasil mencapai derajat subjective well being hidupnya akan penuh dengan rasa syukur kepada Illahi rabbi atas apa yang dianugerahkan kepadanya. Selain itu, kaya dengan penerimaan dan kepasrahan diri, yang kesemua itu justru akan semakin menguatkan untuk terus hidup lebih baik dan terus lebih baik. ${ }^{8}$

Hal ketiga yang dibutuhkan kaum janda lansia yang berada di bawah bingkai kasih sayang adalah friendship atau fellowship, yakni menjalin pertemanan, perkawanan bahkan mengarahkan pada persahabatan dengan para kaum janda lansia. Hal ini dikarenakan mereka membutuhkan kawan dekat untuk berbagi rasa, sebagai tempat untuk bercerita atas keluh kesah yang dimiliki. Dengan persahabatan inilah,menjadi media yang tepat bagi salah satu pihak yang menjadi tempat sandaran untuk memasukkan nuansa-nuansa husnudzan (berbaik sangka) kepada para kaum janda lansia dalam menjalani hidup. Ahmad Sagir dalam bukunya berjudul Husnudzan dalam Perspektif Psikologi menyatakan bahwa sumber dari kedamaian hidup sejatinya adalah pengkayaan diri dengan sikap husnudzan kepada Allah, dengan sikap inilah akan terbangun pikiran-pikiran positif sehingga tatkala menapaki hidup akan terasa ringan tanpa beban, meski sesugguhnya memiliki beban cobaan yang berat. ${ }^{9}$ Dalam hal ini para kaum janda lansia sangat membutuhkan kawan dan

7 Azam Syukur Rahmatullah, "Penanganan Kenakalan Remaja Pecandu NAPZA dengan Pendidikan Berbasis Kasih Sayang (Studi Di Pondok Remaja Inabah XV Putra Pondok Pesantren Suryalaya Tasikmalaya)",Seri Disertasi, Pascasarjana Universitas Muhammadiyah Yogyakarta, 2013.

8 Azam Syukur Rahmatullah, Psikologi Penderitaan, (Kebumen: Azkiya Media, 2015) hlm. 105.

9 Ahmad Sagir, Husnuzzan dalam Perspektif Psikologi, (Yogyakarta: Mitra Pustaka, 2011) hlm.53. 
sahabat yang mampu mencerahkan pikiran dan membawa mereka ada area husnudzan.

Hal keempat yang dibutuhkan kaum janda lansia adalah personal adjusment. Di dalam personal adjusment terdapat poin-poin penting yang mampu mendamaikan perasaan dan kejiwaan kaum janda lansia, yakni adanya penghargaan bagi mereka. Para kaum janda lansia sangat membutuhkan penghargaan dari orang-orang sekitarnya, meskipun penghargaan yang sifatnya ringan, seperti ucapan terima kasih. Hal ini disebabkan secara kejiwaan kaum lansia mudah trenyuh, mudah sedih, mudah terbawa emosi dan pikiran. Kondisi yang demikian perlu dicegah dengan hal-hal yang membuat mereka tidak gelisah dan resah, yang salah satunya adalah menghargai semua tindak tanduk kebaikan yang mereka lakukan.

Hal kelima yang tidak kalah penting yang dibutuhkan kaum janda lansia adalah memperkaya mereka dengan sisi religiusitas-illahiyah, yakni upaya melekatkan diri dengan Sang Hyang Pencipta. Para kaum janda lansia idealnya dibantu untuk selalu dekat dan lekat dengan Tuhannya, karena dengan semakin dekat dan lekat dengan Tuhannya, akan semakin memperingan beban dan tekanan diri. Hal ini dikarenakan mereka merasa bahwa ada Dzat Hyang Maha Menolong, adanya Dzat Hyang Maha memperingan keadaan, dan hal ini otomatis membawa dampak pencerahan diri yang baik dari para janda lansia tersebut. Namun berbeda apabila semakin jauh dan menjauh dari Tuhan, beban diri semakin berat, sebab mereka merasa hidup hanya sendiri, tidak ada yang mampu membantunya, sehingga mata batin semakin tertutup, dan melupakan Sang Hyang Maha Pencipta, akibatnya kondisinya semakin memprihatinkan. Oleh karenanya menjadi kewajiban bagi siapapun untuk membawa para janda lansia untuk aktif bertemu Tuhannya agar semakin tercerahkan dalam hidup.

\section{LSM Luh Jinggan, Potret Kekinian yang Memperdulikan Kaum Janda Lansia dengan Pendekatan Kasih Sayang}

Upaya mensejahterakan psikologis para kaum janda lansia di atas, dilaksanakan sepenuhnya oleh Lembaga Swadaya Masyarakat (selanjutnya disingkat LSM) yang terbilang unik. Sebab umumnya Lembaga Swadaya 
Masyarakat menstressingkan pada bidang pemberdayaan dan pemerhatian anak yatim, yatim piatu, anak jalanan, kaum fakir dan miskin. Namun dalam hal ini, LSM yang diberi nama LSM Luh Jinggan menstressingkan pada pemberdayaan dan pemerhatian bidang kaum janda dan duda lansia, yang mana mereka tidak mampu memberdayakan diri mereka sendiri.

LSM Luh Jinggan didirikan pada bulan Januari 2014 oleh Nurul Fitriyah Awaliyatul Laili, M.Pd.I yang juga merupakan Kepala Madrasah Aliyah Plus "Nururrohmah" Pondok Pesantren Al-Kamal Tambaksari Kuwarasan Kebumen. Pendirian dengan No Notaris Darmono SH: 133/27-01-2014 dan No Pengadilan: 23/HK.02.01/318/2014. Motto yang diunggulkan dan berupaya diterapkan dengan baik oleh pihak LSM adalah khairu an-nās anfäuhum li an-nās, yang berarti sebaik-baik manusia adalah yang paling bermanfaat bagi manusia lain. Bersumber dari motto mulia inilah LSM Luh Jinggan didirikan dengan asumsi mampu membawa manfaat positif bagi para kaum janda dan duda lansia.

Hal yang menjadi pertanyaan adalah mengapa LSM Luh Jinggan dibawah naungan Madrasah Aliyah Plus Nururrohmah Pondok Pesantren Al-Kamal? Hal ini dikarenakan dari mulai ide pendirian serta seluruh stake holder dan pengurus berasal dari dewa asatidz (guru) di Madrasah Aliyah Plus "Nururrohmah." Hal inilah yang membedakan dengan LSM-LSM lainnya. Berawal dari kegelisahan para dewan guru di Madrasah Aliyah Plus "Nururrohmah" Pondok Pesantren Al-Kamal yang merasa resah dikarenakan di sekitar lingkungan Pesantren dan Madrasah Aliyah banyak terdapat janda lansia yang hidupnya memprihatinkan dan membutuhkan banyak sentuhan berbasis kasih sayang. Ada banyak dari mereka yang hidupnya di bawah garis kemiskinan. Hal inilah yang menjadikan asabab-musabab LSM Luh Jinggan berada di bawah naungan Madrasah Aliyah Plus "Nururrohmah" Pondok Pesantren Al-Kamal.

Sehubungan dengan keberadaan LSM Luh Jinggan berikut akan dipaparkan visi, misi, serta program yang ada pada LSM Luh Jinggan, yang kesemuanya kental dengan nuansa pendekatan kasih sayang. ${ }^{10}$

10 Sumber dari dokumen LSM Luh Jinggan, yang diambil pada tanggal 25 Juni 2016 


\section{Visi LSM Luh Jinggan}

Menjadi Lembaga Swadaya Masyarakat (LSM) yang Murni Membantu Sesama Karena Illahi Rabbi, dan Berpijak pada Ruh-Ruh Agama yang Hakiki

Visi ini dibangun dengan harapan:

a. Berorientasi penuh untuk menolong sesama bukan karena ada tendensi/pamrih apapun, kecuali hanya menolong karena Allah Ta'ala.

b. Menstabilkan diri untuk tetap meluruskan niat, memurnikan hati, dan mensucikan jiwa untuk senantiasa membantu sesama dan meringankan beban penderitaan sesama.

c. Berpijak pada nilai-nilai agama, berjuang untuk sesama dengan landasan agama yang dianut dengan sesungguhnya.

\section{Misi}

Berlandaskan dari visi, maka penjabaran dari misi ke depan LSM 'Luh Jinggan' ini adalah;

a. Mengentaskan penderitaan masyarakat terkhusus 'masyarakat tua' (janda/duda tua) guna menuju Indonesia bebas derita bagi 'masyarakat tua' (janda/duda tua).

b. Membangun koordinasi dan kemitraan yang sehat dengan pihakpihak yang memiliki visi, misi, dan tujuan yang serumpun untuk membantu pemerintah membebaskan masyarakat dari penderitaan/ beban mental.

c. Mewujudkan harmonisasi-kedamaian perilaku dan jiwa kepada kaum janda/duda tua khususnya, dengan pengembangan sumber daya manusia (buman resources) manakala masih dimungkinkan bagi mereka.

\section{Sasaran Bantuan Sosial/Kemanusiaan}

LSM 'Luh Jinggan' memberikan bantuan sosial kemanusiaan-untuk sementara waktu-dikhususkan kepada para janda/duda tua yang 
memang benar-benar membutuhkan uluran tangan dan 'perhatian khusus', dengan beberapa kriteria;

a. Janda/duda tua yang tergolong fakir dan miskin yang tidak memiliki pekerjaan yang layak.

b. Janda/tua yang berumur di atas 60-an tahun atau di bawah umur tersebut, tetapi dalam kondisi yang benar-benar memprihatinkan.

c. Janda/tua yang tidak memiliki keturunan/anak dan atau memiliki anak/keturunan namun tidak mampu menafkahi orangtuanya karena memiliki beban perekonomian yang memprihatinkan pula.

d. Janda/duda tua yang sakit-sakitan, tidak mampu menghidupi dirinya sendiri.

e. Janda/duda tua yang tidak memiliki rumah/tempat tinggal atau yang selama ini menumpang pada orang lain.

f. Janda/duda tua yang tidak mendapat pensiunan PNS/atau memiliki anak yang dikategorikan mampu menghidupi/membantu orangtuanya.

g. Janda/duda tua yang ditelantarkan anaknya sendiri sehingga tidak terurus dengan catatan anak kandungnya meski mampu sama sekali tidak memperdulikan nasib orangtuanya sendiri.

h. Janda/duda tua yang tidak memiliki sanak saudara dan kehidupannya terlantar, atau memiliki sanak saudara namun tidak ada satupun yang memperdulikan nasibnya.

\section{Program Kegiatan}

Pendirian dari LSM 'Luh Jinggan' memiliki beberapa program, di antaranya;

a. Memberikan santunan harian, mingguan, dan bulanan (disesuaikan kondisi) kepada para kaum janda/duda tua berupa santunan materi agar mereka terkurangi beban kesulitan perekonomian.

b. Memberikan bantuan biaya hidup selama janda/duda mengalami sakit tua, apalagi tidak ada yang bersedia memikirkan kehidupannya.

c. Memberikan bantuan biaya sakit yang terjangkau dengan 
kemampuan pihak LSM 'Luh Jinggan'.

d. Memberikan bantuan pakaian layak pakai bagi kaum janda/duda tua.

e. Memberikan bantuan menguruskan jamkesmas/BPJS agar mereka mendapatkan hak sehat dari Negara.

f. Memberikan bantuan biaya pengurusan jenazah bagi para kaum janda/duda tua.

g. Memberikan bantuan mencarikan tempat tinggal bagi yang tidak memiliki tempat tinggal'.

h. Memberikan bantuan perlengkapan rumah tangga bagi yang belum memiliki.

i. Memberikan pelayanan konseling kejiwaan/spiritual.

j. Mengunjungi para kaum janda/duda lansia ke rumah-rumah dan mendengarkan keluh kesah mereka.

k. Berupaya mencarikan guru pembimbing mengaji, dan berbagai ibadah untuk meningkatkan kualitas iman dan Islam bagi para kaum janda/duda lansia.

Mendasarkan dari pemaparan di atas semakin menguatkan dengan jelas bahwa berbagai hal yang berhubungan dengan LSM Luh Jinggan, seperti visi, misi, sasaran bantuan sosial/kemanusiaan dan berbagai program, bemuatan penuh kasih sayang. Hal ini dapat dilihat dari visi yang pijakan dasarnya menolong dan membantu hanya karena Allah Tảala, bukan karena bisnis atau ingin menumpuk kekayaan dari bantuan-bantuan yang ada untuk kepentingan pribadi. Kemudian, dapat dilihat dari misi yang bermaksud untuk mengentaskan penderitaan masyarakat janda/duda tua dengan harmonisasi jiwa yang menuju kedamaian. Hal ini tentu saja sangat kuat ruh kasih sayangnya. Selain itu, tentang sasaran bantuan sosial dan kemanusiaan serta berbagai program kegiatan tampak bermuatan kasih saying, baik kasih sayang yang diwujudkan secara materi seperti memberikan berbagai hal untuk mencukupi kebutuhan hidup mereka, maupun yang bermuatan immateri yang mengarah pada ketenangan jiwa. 
Beberapa kegiatan dan program yang tersebut di atas mengarah pada zona secure attachment antara lain memberikan santunan, baik sifatnya harian, mingguan maupun bulanan, berupaya memikirkan kelangsungan hidup para janda dan duda lansia, selain itu memberikan pelayanan konseling secara kejiwaan dan spiritual. Menurut Allen N Mendler, ikatan personal akan semakin kuat manakala terdapat pembiasaan yang mengarah pada penyatuan hati dan jiwa yang di dalamnya kental nuansa kasih sayang. ${ }^{11}$ Dalam hal ini kegiatan yang dilakukan LSM Luh Jinggan merupakan sarana untuk memperkuat ikatan personal dan berupaya untuk memberi rasa aman terutama bagi para kaum janda lansia. Apalagi di dalamnya terdapat kegiatan memotivasi para kaum janda dan duda lansia dengan pendekatan yang kaya dengan kekeluargaan (friendship). Kegiatan tersebut ditunjukkan dengan adanya program councelling yang dilakukan ke rumah-rumah para kaum janda/duda lansia. Dalam hal ini pihak LSM Luh Jinggan berupaya untuk membangun komunikasi interpersonal, yang menurut Suciati, komunikasi ini dibangun untuk menciptakan keintiman dalam hubungan antar sesama. Salah satu tanda berhasilnya bangunan komunikasi yang intim adalah adanya perasaan bahagia, legowo, interaksi yang hangat antara kedua pihak yang saling berinteraksi, yang ending-ya membawa pada titik kedamaian sejati. ${ }^{12}$ Adapun kegiatan berupa rich of religious-spirituality yang dilakukan oleh LSM Luh Jinggan adalah berupaya mencarikan guru pembimbing mengaji, dan berbagai ibadah untuk meningkatkan kualitas iman dan Islam bagi para kaum janda/duda lansia. Selain itu, berupa memberikan pelayanan konseling kejiwaan/spiritual. Kedua program tersebut mengarah pada bangunan komunikasi transendental. Menurut Suciati komunikasi transendental merupakan interaksi kepada Tuhan dengan maksud untuk mencerahkan jiwa sehingga lebih dekat dan lekat dengan Tuhannya. Ketika sampai pada tahapan dekat dan lekat dengan Tuhannya akan menjadikan manusia selalu damai meskipun berbagai ujian dan hantaman datang mendera. ${ }^{13}$

$\overline{11}$ Allen N Mendler, Mendidik dengan Hati, penerj. Edriyano Azwaldi, (Jakarta: Kaifa, 2010), hlm.41.

12 Suciati, Komunikasi Interpersonal, Sebuah Tinjauan Psikologis dan Perspektif Islam, (Yogyakarta: Buku Litera, 2015), hlm. 3.

13 Suciati, Komunikasi Transendental, Implementasi Komunikasi Islami dalam Lingkup Praktek dan Keilmuan, (Yogyakarta: LP3M Universitas Muhammadiyah Yogyakarta, 2016), hlm.118. 
Ending-nya, program kegiatan bebasis kasih sayang yang dilaksanakan oleh LSM Luh Jinggan perlu ditingkatkan dan dieksiskan keberadaannya, sebab kegiatan ini bersifat memuliakan orang lain dan membawa orang lain pada posisi yang mensejahterakan. Di sisi lain para lansia merasa mendapatkan dukungan sosial, sesuatu yang memang sangat dibutuhkan oleh mereka. Sebagaimana hasil temuan Dinie Ratri Desiningrum yang menyatakan bahwa adanya hubungan positif antara persepsi terhadap dukungan sosial dan kesejateraan psikologis pada lansia $(r=0,739 ; p<0,001)$. Hasil Uji-t menunjukkan lansia janda/duda memiliki persepsi lebih positif terhadap dukungan sosial $(t(35)=3,594 ; p<0,001)$ dan menunjukkan kesejahteraan psikologis yang lebih baik daripada lansia duda/janda $(t(42)=2,944 ; p=$ $0,004)^{14}$.

\section{E. Mensejahterakan Psikologis Kaum Lansia dengan Kasih Sayang dan Dalil Naqli yang Menyertainya}

Program kegiatan yang dilaksanakan oleh LSM Luh Jinggan yang berbasis kasih sayang selaras dengan apa yang diajarkan oleh Al-Quran dan Hadis. Beberapa ajaran yang dimaksud adalah pertama, ajaran untuk memuliakan kaum lansia. Rasulullah Saw. bersabda "Sesungguhnya termasuk pengagungan kepada Allah adalah memuliakan orang yang sudah beruban lagi muslim, memuliakan ahli Qur'an dengan tidak berlebihan dan tidak menyepelekannya dan memuliakan para pemimpin yang berbuat adil. ${ }^{15}$ Dalam Hadis lain Rasulullah Saw. menyatakan "Bukan ternasuk golongan kami orang yang tidak menyayangi anak-anak kecil dan tidak menghormati orang tua. ${ }^{16}$

Berdasarkan kedua Hadis di atas terlihat adanya kewajiban untuk menghormati orang yang sudah lansia, yakni ..... "dan menghormati orangorang tua dari kami."Wujud penghormatan adalah tidak menghardik para kaum lansia, tidak menyakiti perasaannya, dan tidak menjadikan kejiwaan mereka terganggu, tetapi sebaliknya yakni menjadikan kejiwaan mereka damai

14 Dinie Ratri Desiningrum, "Kesejahteraan Psikologis Lansia Janda/Duda Ditinjau dari Persepsi Terhadap Dukungan Sosial dan Gender”,Jurnal Psikologi UndipVol.13 No.2 Oktober 2014, 102106

15 HR. Abu Dawud : 4843 dihasankan oleh Syaikh Albani dalam Shahih al-Jami' No. 2199

16 HR. Tirmidzi: 1842; AS-Shahihah No. 2196 
dan sentosa. Hal kedua yang harus dilakukan kepada kaum lansia adalah memuliakannya, sebagaimana Hadis yang menyebutkan "Sesungguhnya termasuk pengagungan kepada Allah adalah memuliakan orang yang sudah beruban lagi muslim." Wujud memuliakannya dengan jalan memperbagus pergaulan dengan para kaum lansia, menampakkan kecintaan kepada mereka serta memperbagus panggilan kepada mereka.

Bentuk pemuliaan kepada kaum lansia terutama kaum janda adalah dengan memperhatikan kesehatan mereka, baik kesehatan fisik maupun kesehatan jiwa. Hal ini dikarenakan kaum lansia merupakan kaum yang lemah dari aspek fisik dam kejiwaannya. Hal ini selaras dengan pernyataan Allah dalam QS. Ar-Rum ayat 54, yang berbunyi:

Artinya: Allah, Dialah yang menciptakan kamu dari Keadaan lemah, kemudian Dia menjadikan (kamu) sesudah Keadaan lemah itu menjadi kuat, kemudian Dia menjadikan (kamu) sesudah kuat itu lemah (kembali) dan beruban. Dia menciptakan apa yang dikehendaki-Nya dan Dialah yang Maha mengetahui lagi Maha Kuasa.

Kedua, ajaran untuk memberikan kasih sayang tanpa syarat kepada para kaum lansia, terutama para janda dan duda tua. Muhammad Anis (2010:5355) menyatakan bahwa sebenarnya Allah telah mengajarkan kepada umat manusia untuk senantiasa memiliki sifat rahmah, yakni sifat yang penuh kasih sayang terhadap makhluk-makhluk sesama manusia maupun selain manusia, sebab yang menyayangi akan selalu memberikan kebaikan kepada yang disayangi.Hal ini selaras dengan pernyataan Quran yang berbunyi:

Artinya: Dan tiadalah Kami mengutus kamu, melainkan untuk (menjadi) rahmat bagi semesta alam.

Prinsip yang dikembangkan oleh LSM Luh Jinggan sebagaimana terlihat pada visi, misi, dan berbagai program kegiatan adalah tolong-menolong. Prinsip ini selaras dengan perintah Allah dalam Quran QS. Al-Māidah Ayat 2.

Artinya: Dan tolong-menolonglah kamu dalam (mengerjakan) kebajikan dan takwa, dan jangan tolong-menolong dalam berbuat dosa dan pelanggaran. dan bertakwalah kamu kepada Allah, Sesungguhnya Allah amat berat siksaNya. 
Menurut Ibnu Katsir memahami makna umum ayat ini berdasarkan redaksinya bahwa Allah Swt.. memerintahkan semua hamba-Nya agar senantiasa tolong-menolong dalam melakukan kebaikan. Termasuk kategori Al-birr dan mencegah dari terjadinya kemungkaran sebagai realisasi dari takwa. Sebaliknya Allah Swt.. melarang mendukung segala jenis perbuatan batil yang melahirkan dosa dan permusuhan.

Ayat lain yang merujuk pada prinsip tolong-menolong yang menjadi pondasi LSM Luh Jinggan adalah QS.At-Taubah ayat 71:

Artinya: Dan orang-orangyang beriman, lelaki dan perempuan, sebahagian mereka (adalah) menjadi penolong bagi sebahagian yang lain. mereka menyuruh (mengerjakan) yang ma'ruf, mencegah dari yang munkar, mendirikan shalat, menunaikan zakat dan mereka taat pada Allah dan Rasul-Nya. mereka itu akan diberi rahmat oleh Allah; Sesungguhnya Allah Maha Perkasa lagi Maha Bijaksana.

Kalimat "sebahagian mereka menjadi penolong bagi sebahagian yang lain" ini merupakan kalimat "penjelas" yang menunjukkan tingkat rasa cinta yang menciptakan rasa perdamaian, keharmonisan, penghargaan, welas asih antar sesama. Tidak adanya saling menghakimi, saling mengunggul-unggulkan diri dan saling "merasa benar sendiri". Hal inilah yang diteladani sebagai bagian dari akhlak mahmudāh. Imam Nawawi al-Bantani dalam kitabnya Nashāihul Ibād menyatakan salah satu tujuh golongan yang tidak akan dirahmati Allah pada hari kiamat, yakni orang-orang yang tidak dapat menjadi penolong bagi orang lain terutama tetangga dekatnya sendiri, bahkan seringkali menyakiti. ${ }^{17}$

\section{F. Kesimpulan}

Berdasarkan dari pemaparan di atas terlihat dengan jelas bahwa kaum lansia pada hakikatnya tidak hanya membutuhkan hal-hal yang bersifat kebendaan saja, tetapi hal-hal yang bersifat immateri, yakni berupa dukungan moral, dukungan sosial, perhatian, secure attachment, motivasi, persahabatan yang kesemuanya berbingkai kasih sayang. Dengan hal-hal yang bersifat

17 Imam Nawawi al-Bantani, Nashäikhul Ibād; Nasihat-nasihat untuk Para Hamba Menjadi Santun dan Bijak, terj. Fuad Kauma, (Bandung: Irsyad Baitus Salam, 2005), hlm. 205. 
immateri inilah para lansia mampu berdiri tegak meski berbagai ujian Tuhan menyertai, dan dengan dorongan immateri ini pula menjadi wasilah untuk mensejahterakan psikologi para kaum janda lansia. Oleh karenanya perlu dimaksimalkan pemberdayaan atas program kegiatan yang bersifat materi dan immateri kepada para kaum janda lansia sehingga mereka merasa dimanusiakan sebagai makhluk sosial.

\section{Daftar Pustaka}

Anis, Muhammad. 2010.Quantum al-Fatihah; Membangun Konsep Pendidikan Berasis Surah al-Fatihah.Yogyakarta: Pedagogia

Buletin Jendela Data dan Informasi Kesehatan, semester I tahun 2013, ISSN 2088-270X.

Desiningrum, Dinie Ratri. "Kesejahteraan Psikologis Lansia Janda/Duda Ditinjau dari Persepsi Terhadap Dukungan Sosial dan Gender.” Jurnal Psikologi Undip Vol.13 No.2 Oktober 2014, 102-106

Fitrianingrum, Enita dan Legowo, Martinus. "Strategi Bertahan Hidup Janda Lansia.” Jurnal Paradigma. Volume 02 Nomer 03 Tahun 2014

Imam Nawawi al-Bantani. 2005. Nashäikhul Ibād; Nasihat-nasihat untuk Para Hamba Menjadi Santun dan Bijak. Terj. Fuad Kauma. Bandung: Irsyad Baitus Salam.

Kartono, Kartini. 2010. Patologi Sosial, Gangguan-gangguan Kejiwaan. Jakarta: PT Raja Grafindo Persada.

Mardiana, Yanih dan Zelfino. "Hubungan Antara Tingkat Stress Lansia dan Kejadian Hipertensi pada Lansia di RW 01 Kunciran Tangerang." Forum Ilmiah, Volume 11 Nomor 2, Mei 2014261.

Mendler, Allen N. 2010. Mendidik dengan Hati. Terj. Edriyano Azwaldi. Jakarta: Kaifa.

Notosoedirdjo, Moeljono dan Latipun. 2014. Kesehatan Mental, Konsep dan Penerapan. Malang: UMM Press.

Rahmatullah, Azam Syukur. 2015. Psikologi Penderitaan. Kebumen: Azkiya Media. 
. 2013. "Penanganan Kenakalan Remaja Pecandu NAPZA

dengan Pendidikan Berbasis Kasih Sayang (Studi Di Pondok Remaja Inabah XV Putra Pondok Pesantren Suryalaya Tasikmalaya)". Seri Disertasi. Yogyakarta: Pascasarjana Universitas Muhammadiyah Yogyakarta.

Sagir, Ahmad. 2011. Husnuzzan dalam Perspektif Psikologi. Yogyakarta: Mitra Pustaka.

Suciati. 2015. Komunikasi Interpersonal, Sebuah Tinjauan Psikologis dan Perspektif Islam. Yogyakarta: Buku Litera.

.2016. Komunikasi Transendental, Implementasi Komunikasi Islami dalam Lingkup Praktek dan Keilmuan. Yogyakarta: LP3M Universitas Muhammadiyah Yogyakarta.

Zuchdi, Darmiyati. 2010. Humanisasi Pendidikan, Menemukan Kembali Pendidikan yang Manusiawi. Jakarta: Bumi Aksara. 